\title{
Pathological Study of Streptococcus faecalis Antigen-induced Arthritis in New Zealand White Rabbits
}

\author{
Hiroaki YAMAMOTO and Takashi KOMATSUZAKI* \\ Department of Pathology, The Kohno Clinical Medicine Research Institute, 3-3-7 \\ Kitashinagawa, Shinagawa-ku, Tokyo 140, Japan and *Section of \\ Microbiology, Tomidahama Hospital, 26-14 Tomidahama, \\ Yokkaichi-city, Mie 512.
}

(Received 7 May 1986/Accepted 24 September 1986)

\begin{abstract}
The pathological examination of the rabbit knee joint with antigen-induced arthritis produced by heat-killed Streptococcus faecalis (Str. faes.) as antigen was carried out. Macroscopically, there were findings of acute inflammation about five hours after the injection. Histopathologically, very remarkable acute exudative inflammation was seen 48 hours later. This supponted the picture of Arthus reaction. The Arthus reaction disappeared with time, and this supported the view of delayed-type hypersensitivity three weeks later. After that, an obvious chronic inflammation was admitted in 10 weeks. This resembled the histopathological feature of rheumatoid arthritis (RA) when these findings are summarized. It was suggested that arthritis produced by Str. faec. progresses from an acute condition to a one with time. As mentioned above, it thought that Arthus reaction of both immediate hypersensitivity and delayed-type hypersensitivity are necessary in the occurrence of this arthritis.
\end{abstract}

\section{Streptococcus faecalis によるウサギの抗原誘導関節炎の 経時的病理学的研究}

\author{
山本博昭 · 小松崎 尚* \\ 財団法人河野臨牀医学研究所病理学研究窒 \\ *医療法人富田浜病院研究部微生物学研究窒
}

ヒトの慢性関節リウマチ（RA）の成因を探る上で実 験的関節炎の動物モデルは極めて意義がある [1]。実験 的関節炎の発症の試みの一つとしては免疫学的機序をあ とに関節炎を惹起させる方法あある。その代表的なあの には Dumonde and Glynn [2] によるフィブリンを Freund's の incomplete adjuvant とともにウサギに感 作した後, 関節腔内にフィブリンを 1 回注射して発生さ せた抗原誘導慢性関節炎がある。その後 Consden ら [3]
の卵白アルブミンや Cooke and Jasin [4] の牛血清ア ルブミンおよび最近ではフェリチンによる抗原誘導関節 炎等が報告された $[5,6]$ 。乙れらのモデルは慢性関節炎 が惹起され，その病理像がRAに類似しているととより RA のモデルとして広く利用されて，特に関節炎の慢性 化の過程の解析が行われてきた $[7,8,9,10]$ 。

小西ら $[11,12]$ はA と Streptococcus faecalis (Str. faec.) との関係を明らかにする目的で Str. facc. 
によるウサギの実験的関節炎の誘発について報告してい る。乙の関節炎は急性に始まり慢性へと移行し, その病 理像はRAの組織像にも似た特異的な慢性炎症を呈して いた $[13]$ 。

今回 Str. faec. による関節炎の発生機序の解明の一 助として Str. faec. の加熱死菌を抗原としてウサギに 抗原誘導関節炎を惹起させて経時的に関節の変化を病理 学的に検討した。

\section{材料および方法}

ウサギ：中部科学資材株式会社より 12 週路の Nwe Zealand White (NZW) の雌を入手した。飼育条件は 温度 $23 \pm 1{ }^{\circ} \mathrm{C}$, 湿度 $55 \pm 10 \%$, 照明時間 12 時間/ 1 日で, 固型飼料（CR-3，日本クレア）を 1 日 $200 \mathrm{~g}$ の制限食之 飲水は自動給水操置で自由摄取とした。

抗原の作成：菌株 Str. faec. は東京大学医科学研究 所より分与された IIID-10541 を用いた。凍結保存した Str. faec. は BHI broth に 40 時間予備培養して, さ らに Mod. HI agar で 24時間培養した。これらの菌体 を集めて滅菌脱脂綿で沪過した菌液は $4^{\circ} \mathrm{C} に て 4,000 \mathrm{rpm}$, 20分間遠沈した。乙れを生理食塩水で 3 回洗浄して Str. faec. が $20 \mathrm{mg} / \mathrm{wet} / \mathrm{ml}$ になるように生理食塩水で調整 後, $100^{\circ} \mathrm{C}$ で30分加熱して Str. faec. 加熱死菌とした。 この死菌は $10 \mathrm{mg} /$ wet $/ 0.5 \mathrm{ml}$ 量を Freund's の incomplete adjuvant（FIA：和光純薬）に混ぜて w/o 型の 乳濁液とした。

免疫方法：25匹のウサギの背部の筋肉内に毎月 1 回, 計 6 回 Str. faec. 加熱死菌の $10 \mathrm{mg}$ 量を注射した。ウ サギの血清中の Str. faec. 亿対する凝集抗体価*を確 認後, 左膝関節腔に $1 \mathrm{mg} / 0.5 \mathrm{ml}$ の Str. faec. 加熱死 菌を 1 回注射して抗原誘導関節炎を発生させた。ウサギ は膝関節注射後 48 時間目，1，3，5，10 週間目にネンブ タールの静脈内投与での麻酔下で頸動脈より全採血によ り死に至らしめ剖検を行った。

病理学的検索: 光顕用滑膜組織は10\%中性緩衝ホルマ リンで固定後, 常法によりパラフィン切片とし, Hematoxylin and Eosin (H-E), azan Mallory, Weigert $の$ 線維素, alcian blue, periodic acid Schiff (PAS), phosphotungstic acid hematoxylin (PTAH) 染色を施 した。
免疫組織化学的には抗ウサギ IgG, IgM, C 3 (CAPPEL LABORATORIES INC) 血清を用いてパラフ ィン切片での Peroxidase-antiperoxidase (PAP) 法に て検索した。

電顕的には剖検時に滑膜組織を細切し， $2.5 \%$ glutaraldehyde および $1 \%$ Osmium acid の二重固定を行い, 脱水後 Epon 包埋して超薄切片を作成した。切片は酢 酸 uranyl と酢酸鈶の二重電子染色を施して電子顕微鏡 （JEM-100 SX；日本電子）にて観察した。

成

25匹のウサギの膝関節腔へStr.faec. 加熱死菌を注 射した後, 約 5 時間目頃より全例に熱感と軽度の腫脹が みられ，急性炎症が惹起した。

以下，経時的な関節の変化は全例に認められ，その変 化の質や程度にはほとんど個体差はみられなかった。そ れらの主な肉眼的および組織学的所見は Table 1 と 2 に各々示した。

48 時間目：未処置対照の膝関節の外径を $0 \mathrm{~mm}$ とした 場合，処置した膝関節の平均は $5.5 \pm 0.19 \mathrm{~mm}$ と高値を 示した。関節の外観は浮腫性で細血管の著しい拡張と迂 曲を認めた (Fig. 1)。関節腔では血性で粘稠度の低下し た滑液が増量していた。滑膜組織は肥厚し，表面は充 血，粗造でフィブリン様物質の付着や出血斑で混濁して いた。

組織学的に滑膜は浮腫, 充血, 出血および極めて著し い多核白血球の浸潤がみられる急性炎で，滑膜表層細胞 は変性壊死, 脱落および消失し，その表層部位にはフィ ブリンまたはフィブリノィドの沈着を認めた（Fig. 2)。

免疫グロブリン IgG と IgM および補体 C 3 の沈着 は滑膜表層下の血管の壁と内腔の一部にみられ，さらに 少数の多核白血球にも認められた。

電:顕的に滑膜は変性や壊死および破壊された同定不明 な紐胞が多数を占め, 少数の滑膜表㟄細胞と思われるも のた多くの多核白血球が浸潤していた。また，細胞間質 では変性断裂した膠原線維束が散在していた。

1 週間目 : 関節の外径は $45 \pm 0.19 \mathrm{~mm}$ で 48 時間目の 值より若干減じていた。しかし，その他の肉眼的所見に は前期の変化と大差はみられず, 関節外部の浮腫, 紼血 管の拡張之迂曲，血性状滑液の増量と滑膜組織の肥厚は

* 凝集抗体価の測定法：凝集抗原は免疫原に用いた Str. faec. の加熱死菌と同様に作り，常法のごとく定量凝集反応をマイク口 タイター法にて行った。その反忘の概略は血清を非㗢化の後, 2 倍采列希釈を行い（生理食塩水・リン酸緩衝液, pH 7.2), 抗

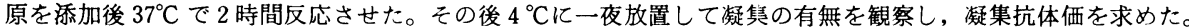


Table 1. Major gross findings of the knee joint in NZW rabbits treated with Str. faec.

\begin{tabular}{|c|c|c|c|c|c|c|}
\hline & \multirow[b]{2}{*}{ Total } & \multicolumn{5}{|c|}{ Time of investigation } \\
\hline & & 48-hour & 1-week & 3-week & 5-week & 10-week \\
\hline Number of rabbits & 25 & 5 & 5 & 5 & 5 & 5 \\
\hline \multicolumn{7}{|l|}{ Exterior } \\
\hline Swelling (mm) & & $5.5 \pm 0.19$ & $4.5 \pm 0.19$ & $3.5 \pm 0.32$ & $1.5 \pm 0.29$ & $2.0 \pm 0.22$ \\
\hline Edema & & $+++*$ & $++t$ & ++ & - & - \\
\hline Extension of vessele & & ++ & ++ & ++ & + & - \\
\hline \multicolumn{7}{|l|}{ Interior } \\
\hline Synovial fluid & & +++ & +++ & +++ & + & + \\
\hline Hyperemia & & ++ & + & + & - & - \\
\hline Hemorrhage & & ++ & + & + & - & - \\
\hline Thickening of synovial tissue & & +++ & $+t+$ & +++ & ++ & + \\
\hline Clouding of synovial tissue & & +++ & $+t+$ & ++ & \pm & - \\
\hline Roughness of synovial tissue & & $++t$ & $+t+$ & ++ & \pm & - \\
\hline
\end{tabular}

- : negative, \pm : weak; $+:$ moderate; $++:$ more than moderate; +++ strong.

* Highest score out of five animals.

Table 2. Major histological findings of the knee joint in NZW rabbits treated with Str. faec.

\begin{tabular}{|c|c|c|c|c|c|c|}
\hline & \multirow[b]{2}{*}{ Total } & \multicolumn{5}{|c|}{ Time of investigation } \\
\hline & & 48-hour & 1-week & 3-week & 5-week & 10-week \\
\hline Number of rabbits & 25 & 5 & 5 & 5 & 5 & 5 \\
\hline Edema of synovial membrane & & $++*$ & +++ & +++ & \pm & - \\
\hline Hyperemia of synovial membrane & & ++ & $+t+$ & ++ & \pm & - \\
\hline Hemorrhage of synovial membrane & & ++ & ++ & + & \pm & - \\
\hline Necrosis of synovial membrane & & +++ & +++ & ++ & + & - \\
\hline $\begin{array}{l}\text { Fibrin and/or fibrinoid on } \\
\text { synovial membrane }\end{array}$ & & ++ & ++ & ++ & ++ & ++ \\
\hline Proliferation of synovial villus & & - & - & - & ++ & +++ \\
\hline Decrease of synovial cells & & +++ & +++ & ++ & + & - \\
\hline Hypertrophy of synovial cells & & - & - & \pm & ++ & ++ \\
\hline Hyperplasia of synovial cells & & - & - & \pm & ++ & $++t$ \\
\hline Polymorph. leukocyte infiltration & & +++ & $+t+$ & ++ & \pm & - \\
\hline Lymphocyte infiltration & & - & \pm & ++ & $+t+$ & +++ \\
\hline Plasma cell infiltration & & - & - & + & ++ & ++ \\
\hline Macrophage infiltration & & - & - & + & + & + \\
\hline Lymphatic node-like formation & & - & - & - & + & ++ \\
\hline Increased blood vessels & & - & - & \pm & + & + \\
\hline Granulation tissues & & - & - & + & ++ & ++ \\
\hline
\end{tabular}

- : negative; \pm : weak; $+:$ moderate $++:$ more than moderate; +++ strong.

* Highest score out of five animals. 
依然として持続していた。

組織学的に滑膜組織は著しい浮腫や充血および多核白 血球の浸潤があり, その浸潤細胞の多くは変性し, 核破 壊に落ち入り壊死産物やフィブリノイド物質と混じて組 織を形成していた。滑膜表層部では表層細胞の再生はま だみられずフィブリンまたははフィブリノィドが沈着し ていた。

$\operatorname{IgG}, \operatorname{IgM}$ 抢よび C 3 の沈着は滑膜表層部のフィブリ ノイドや一部の多核白血球または血管壁に認められた。

電顕的には変性, 壊死および破壊された同定不明な細 胞之ともにわずかに滑膜表酋細胞がみられた。との細胞 は微細構造が変性のため明瞭ではないが, 粗面小胞体が 増加し挔張した $\mathrm{F}$ 型細胞之細胞突起が消失した $\mathrm{M}$ 型細胞 であった。その他, 幼若な多核白血球も認めた。

3 週間目: 関節の外径は $3.5 \pm 0.32 \mathrm{~mm}$ 之前期の值よ りも減じ, 浮腫も軽減した。しかし, 細血管の拡張と迂 曲は持続していた。滑液は粘秱度が低下して増量してい たが, 血性の程度は軽減していた。滑膜組織は依然とし て肥厚し, 表面は粗造で一部にフィブリン様物質が付着 しているが，充血，出血斑ないし混濁は軽減していた。

組織学的に滑膜組織の浮腫や充血, フィブリンないし フィブリノィド沈着は持続していたが，一部の滑膜表層 では腫大と重積をともなった滑膜表層細胞が再生してい た。滑膜表層下では多核白血球に混じてリンパ球や形質 細胞またはマクロファージの浸潤と肉芽形成が認められ た (Fig. 3)。

IgG や IgM は再生した滑膜表層細胞や形質細胞また はマクロファージに顆粒状にみられ，C 3 あ一部の多核

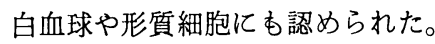

電顕的に滑膜表首細胞は比較的幼若な $\mathrm{M}$ 型ないし $\mathrm{F}$ 型 細胞が再生し, 間質は比較的粗で, 線維芽細胞が多い。 新生した一部の毛細血管では内皮細胞の剝離と基底膜の 断裂がみられ，その部位ではフィブリノイド物質もみら れた。滑膜下層では多核白血球の他にリンパ球ないし形 質細胞が多く, その間には断裂した膠原線維が散在して いた (Fig. 4)。

5 週間目：関節の外径は $1.5 \pm 0.29 \mathrm{~mm}$ と前 3 期の值 からすると著しく減じた。関節周囲の浮腫は消退し, 細 血管の拡張や迂曲は軽減していた。滑液は無色透明で 量, 粘秱度と屯減少していた。滑膜組織屯若干の色調変 化を伴った肥厚を認めるのみであった。

組織学的には滑膜䋐毛は増殖し, 若干の充血や浮腫が みられた。滑膜表層細胞の再生は活発となり腫大した細 胞が数首に重積していた。表層下では肉芽形成が著し
く, 多核白血球は減少してリンパ沪胞様構造や形質細胞 ないしマクロファージの增加がみられた (Fig. 5)。

IgG，IgMないしC 3 は主に形質細胞に沈着していた が，その他，滑膜表首細胞やフィブリノィド沈着部位に あ認められた。

電顕的にも滑膜表層細胞は数を増し, $\mathrm{F}$ 型細胞では粗 面小胞体の発達, $\mathrm{M}$ 型細胞では細胞突起の発達を特徵と し，特に後者の細胞では貪食能を示するのあみられた。 表首下では線維芽細胞の増加, 血管の新生があり, 少数 の多核白血球上多くのリンパ, 形質細胞がみられ, これ らの細胞は比較的幼若型のあのが多かった。

10 週間目: 関節の外径は $2.0 \pm 0.22 \mathrm{~mm}$ 之初期の值か らすると半分以下に減じていた。前期までの諸種変化は 大半が消退し, わずかに滑膜組織の肥厚のみが特徽的で あった。しかし組織学的には滑膜組織の䋐毛増殖は著し く, 表層細胞は腫大と重積していた（Fig.6)。表層下で は肉芽化, リンパ沪胞様構造, 形質細胞やマクロファー ジの浸潤，onion skin-like fibrosis を呈する血管拈よ び脂肪組織や筋組織の再生等が特徵的であった。

免疫組織学的に形質細胞の多くには IgG が明膫に認 められたが (Fig. 7), IgM とC 3 も若干弱いながらも 同一細胞汇沈着していた。その他，乙れらの抗体は滑膜 表層細胞やフィブリノイド物質にもほぼ一致して認めら れた。

電:䫓所見ではM型細胞における細胞突起の発達や系粒 体,リゾゾームないし pinocytic な空胞の増加または荟 食能等がみられ, $\mathrm{F}$ 型細胞での粗面小胞体の増加と拡張 が特徵的であった（Fig. 8)。また少数ながら M型，F型 の両者の特徵を示す細胞も認められた。リンバ球の集蔟 部位では比較的幼若なリンパ球がみられた。形質細胞は 粗面:小胞体とゴルジ一装置が発達し, 胞体表面には細胞 突起がみられ, 電子密度が高い胞体より成る幼若型と核 が偏在した成熟型が混在していた。また, 間質では翏原 線維の増加ないし細血管の発達が特徵的であった。

\section{考察}

小西ら[11]は Str. faec. の死菌をウサギに注射する 之, その菌に対する凝集価, RFLS, CH 50, IgG, シア ル配，CRP および $\gamma$-グロブリンと $\alpha_{2}-$ グロブリンの上 昇な゙いし $\mathrm{A} / \mathrm{G}$ 比の低下を認め炎症を示唆した。その病 理所見であ関節に顕著な炎症がみられ，Str.f fxec. に より関節炎が発生することを明らかにした $[12,13]$ 。そ してこの関節炎の組織像は経時的に急性加慢性炎症へ 
と進展し，特に慢性像において RA の像に類似してい た。

Str. faec. と関節炎との関係については臨床的にヒト の RA 患者の血液や滑液より Str. faec，を高率に分離 したとする報告による $[14,15,16]$ 。今回の研究ではこれ らの事実に基づいて Str. faec. による関節炎の発生機 序を探ることを目的とし，さらにはこの実験系による関 節炎の実験モデル化の可能性をも加へ，Str. faec.の死 菌を抗原として抗原誘導関節炎の誘発について病理学的 に検討した。

Str. faec. の惹起注射後 48 時間目ないし 1 週間目で の関節は渗出性の急性炎症の像であった。乙の病変の成 り立ちはStr. faec. の死菌の注入により, その局所に 抗原抗体反応が惹起して免疫複合体を形成し, 第而型了 レルギーであるアルサス反応が成立したものと考えられ た[10]。一般的にアルサス反応は抗原の注入後 $2 \sim 6$ 時 間目頃より始まり $12 \sim 24$ 時間目頃には最高に達するとい う。今回の実験では初回の組織学的観察が48時間目であ ったが，その所見は比較的顕著なアルサス反応を示唆し ていたことより，それ以前の12～24時間目頃では極めて 著しいアルサス反応が惹起していたものと推察された。 したがって，以上の所見より Str. faec. の死菌は比較 的強い抗原抗体反応を惹起する抗原物質之考えられる。 しかし，乙の時期での組織像には RA の病像との共通所 見は認められなかった。

惹起注射後 3 ないし 5 週間目での関節では渗出性の急 性炎症はみられず，いわゆる Coombs and Gell の第III 型反応が消退して第IV型反応（遅延型過敏症）に類似の 組織がみられた $[17] 。$ 特に 5 週間目の組織像より特異的 なリンパ汇胞様形成がみられ，乙の所見は青木ら $[10]$ の 大腸菌 0：14株によるウサギの抗原誘導関節炎の所見と 一致した。この様なIV型反応では細胞障害性 $\mathrm{T}$ 細胞の活 性化に伴ない Macrophage migration inhibition factor 等の lymphokine が放出されて標的細胞の破壊が考えら れている $[18,19]$ 。

さらに10週間目に至ると滑膜䋐毛の乳頭状増殖, 滑膜 表層細胞の過形成, フィブリノイド沈着, 肉芽形成, リ ンパ汇胞様形成および形質細胞の浸潤等を特徴とする明 らかな慢性関節炎へと移行していた。Glynn [20］は抗 原誘導関節炎の慢性化する機序には細胞性免疫の関与を 指適した。Ziff ら［21］あ抗原誘導関節炎より採取した 滑膜表層細胞を培養すると migration inhibitory factor と migration inhibitory factor-like substance が産生 されたとし，さらに細胞性免疫の mediator である ly- mphokine を正常ウサギの関節内へ注射すると慢性関節 炎が発症したことより細胞性免疫反応が関節炎を惹起し たとしている。このことは Goldberg ら [22]によって あ同様な報告が成されている。大野ら $[23]$ は抗原誘導関 節炎の慢性化の機序を，(1)個体が細胞性免度を獲得して いること, (2)関節軟骨表層に沈着した免疫複合体が persisting antigen として働いていること, (3)関節炎によ って生じた炎症産物や破壊産物に対して自己免疫反応が 考えられる，とし，その中であ(2) の存在に注目してい る。今回の実験では関節軟骨の免疫組織化学的な検討は 行っていないが，免疫グロブリンや補体が滑膜組織のほ ぼ同一な細胞や部位に共通した局在傾向を示したととよ り，てれらは免疫複合体の形で沈着しているあのと考え られた。

一般に抗原誘導関節炎の発症形式は単発性であり多発 性はほとんど発症しないという $[4]$ 。今回の実験でも challenge した膝関節のみに単発した関節炎であった。 しかし, 組織像では特に慢性期のもので前述した如く極 めて特異的な像が得られ，乙れらの像は現在ヒトの RA 所見に最も類似している大腸菌 0：14による実験的関節 炎モデル[24]ないし，ヒトの RA の所見 [25]に似てい た。抗原誘導関節炎と RA を組織学的に比較すると $[1]$, 類似点はリンパ沪胞様形成を伴なう慢性炎症で，関節局 所に免疫グロブリンが産生し，関節軟骨で免疫複合体が 沈着している点である $[25]$ 。一方, 相違点は抗原誘導関 節炎の場合，骨病変や関節外病変がなく，リウマチ因子 あ産生しない点である $[24]$ 。今回の実験でも骨病変や血 管炎またはリウマチ結節等はみられず RA とは区別され た。しかし，Str. faec. を抗原に抗原誘導関節炎を発症 させた場合の発症機序は抗原を注入した関節にアルサス 反応が惹起して，ての反応が消退するにつれて二次的に 遅延型反応が誘発され，次第に慢性像が完成したものと 解した。したがって, Str. faec. による関節炎は上述の 二つの過敏症反応が時期を異にして発現することが誘因 と考えられた。

以上の結果より, 腸内常在菌で, しかも毒性が極めて 弱い Str. faec. の死菌での抗原誘導関節炎は急性炎症 から慢性增殖性炎症に至る過程と慢性化に関する種々の 因子を検討するととはヒトのRAを初めとする他の慢性 関節炎の究明や薬効評価のための病態モデルとして役立 つあのと思われる。 


\section{要 約}

Streptococcus faecalis (Str. faec.) の死菌を抗原亡 して抗原誘導関節炎を発症させ, それの経時的病理学的 検討を行った。

その結果, 肉眼的には抗原の惹起注射後 5 時間目頃よ り急性炎症を示唆する所見が認められたが, 組織学的に は48時間で極めて著しい急性渗出性関節炎の像を呈し, この所見は即時型のアルサス反応の像とほぼ一致した。 以後, 経時的にこの反応は除々に消退して，3 週目には 遅延型反応とほぼ一致する所見が認められた。さらに10 週目では明らかな慢性炎症像がみられ，それらの所見を 総括すると RA の病像に類似していた。

以上の結果より, Str. faec. による関節炎は急性に始 まり慢性に移行することが示唆され，乙の関節炎の発症 には即時型と遅延型の両者の過敏症反応が基本を成して いるすのと思われた。

\section{文献}

[1] 小泉富美朝 (1980). リウマチのモデル動物, リウマチ, 20, 371-382.

[2] Dumonde, D. C., and Glynn, L. E. (1962). The production of arthritis in rabbits by an immunological reaction to fibrin. Brit. J. Exp. Path., 43, 373-383.

[3 ] Consden, R., Doble, A., Glynn, L. E., and Nind, A. P. (1971). Production of a chronic arthritis with ovabumin. Its retention in the knee joint. Ann. Rheum. Dis., 30, 307.

[4] Cook, T. D., and Jasin, H. E. (1972). The pathogenesis of chronic inflammation in experimental antigen-induced arthritis. I. The role of antigen in the local immune response. Arthritis Rheum., 15, 327-337.

[5] 内藤二郎・大野 修 (1981). 慢性関節リウマチにおりる 関節炎の再然之慢性化に関する研究。神戸大学医学部紀 要, 42, 795-813.

[6] Sakata, T., Ohno, O., Ishikawa, H., Hirohata, K., and Cooke, T. D. V. (1984). Pathogenesis of chronic inflammation in experimental ferritin-induced arthritis. V. Electron microscopic localization of specific antibodies in the synovial membrane. $J$. Orthop. Res., 2, 346-355.

[ 7 ] Cook, T. D., Hurd, E. R., Ziff, M., and Jasin, H. E. (1972). The pathogenesis of chronic inflammation in experimental antigen-induced arthritis. $J$. Exp. Med., 135, 323-338.

[8] Cook, T. D., and Richer, S. M. (1974). Pathogenesis of chronic inflammation in experimental antigen-induced arthritis. J. Rheum., 1, 143-152.
[9] Ohno, O., Tateishi, H., and (Cooke, T. D. (1978). Pathogenesis of chronic inflammation in experimental ferritin-induced arthritis. Arthritis Rheum., 21, 81-91.

[10］青木重久·生田耕司・野々垣常正 ・ 伊藤美武 (1979). 腸 内細菌による antigen-induced arthritis の経時的形態 的分析. 東海リウマチ, 10, 75-80.

[11］小西靖彦・関矢正樹・田中利明・田畑昌夫・河野稔彦, 峯 尾 晢 - 山本博昭 - 小松崎 尚 (1985) Streptococcus faecalis による家鬼の関節炎. 前篇, 後篇. 河医研年報. 35, 153-170.

[12］小松崎 尚- 峯尾 哲 - 山本博昭 - 小西靖彦・岸田充弘 (1986). 腸球菌による抗原誘導関節炎家兔の血清C反応性 蛋白とシアル酸, 医学と生物学 $113,5-9$.

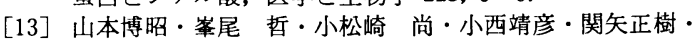
田中利明・田畑昌夫・河野稔彦 (1985). NZW ウサギの 関節に対する Streptococcus faecalis の実験的影響, 特 に病理学的変化について, 実動技誌, 20, 139-143.

［14］河野 稔 - 田沢叔夫 - 深沢甲子婎 - 北川欣也 - 小野三品 吉田高美・椎名文雄・染谷由郎・杉原久義 - 石橋兵衛 (1952). 多発性関節リウマチスの微生物療法. 日本医事新 報, 1472，2282-2286.

[15］矢野良一・畑一郎 (1954). リウマチ患者流血中よりの 緑連菌の検出に就て。日内会誌，43，49-50.

［16］深沢甲子雄（1956）。多発性関節リウマチ患者体液（血液, 関節液) 中の連鎖球菌の検出並びに其の同定に関する研 究。東医大誌，14，168-179。

[17] Zvaifler, N. J. (1979). Etiology and pathogenesis of rheumatoid arthritis. In Arthritis and allied conditions. A textbook of rheumatology. pp. 417 -428. McCarty, D. J. Jr., Lea, and Febiger. (ed.). Philadelphia,

[18- Ishida, M., Honda, M., and Hayashi, H. (1978). In vitro macrophage chemotactic generation from serum immunoglobulin $\mathrm{G}$ by neutrophil neutral seryl protease. Immunology, 35, 167-176.

[19- 森沢成司 (1978). 活性化リンパ球の産生と chemical mediator リンホカイン。 日本臨牀, 36, 937-943.

[20- Glynn, L. E.(1968). The chronicity of inflammation and its significance in rheumatoid arthritis. Ann. Rheum. Dis., 27, 105-121.

[21: Ziff, M. (1974). Relation of cellular infiltration of rheumatoid synovial membrane to its immune response. Arthritis Rheum., 17, 313-319.

[22_ Goldberg, V. M., Lance, E. M., and Davis, P.(1974). Experimental immune synovitis in the rabbit. Relative roles of cell mediated and humoral immunity. Arthritis Rheum., 17, 993-1005.

[23] 大野 修・内藤二郎・坂田敏郎・川井和夫 - 石川 斉 - 広 田和志 (1985). シンポジゥムーII 慢性関節リウマチにお ける動物モデルの進歩と問題点. 2 抗原誘導関節炎. リウ マチ, 25, 428-430.

[24] Aoki, S., Ikuta, K., Nonogaki, T., and Ito, Y. (1985). Induction of chronic polyarthritis in rabbits by hyperimmunization with Escherichia Coli. Arthritis Rheum., 28, 522-528.

[25.] Soren, A. (1978). Histodiagnosis and clinical correlation of rheumatoid and other synovitis. Ist ed., pp. 148-161. J. B. Lipprncott, (ed.). Philadelphia, Tront. 


\section{Explanation of Figures}

Fig. 1. The left and right knee joints of a NZW rabbit 48 hours after injection with Str. faec., showing swelling with edema and convoluted vessels in the left knee joint.

Fig. 2. Synovial membrane of a NZW rabbit shown in Fig. 1., showing acute arthritis with necrosis, disappearance of the lining' cells and infiltration of the many polymorphonuclear leukocytes. H-E stain, X 100.

Fig. 3. After three weeks, showing granulomatous synovitis with regeneration of the lining cells. H-E stain, X 100.

Fig. 4. After five weeks, showing subchronic arthritis with lymphoid cell aggregation appearing as follicles and fibrinoid substances.
H-E stain, X 200.

Fig. 5. After 10 weeks, showing chronic arthritis with lymphoid cell aggregation appearing as follicles within the hypertrophied synovial villus. $\mathrm{H}-\mathrm{E}$ stain, $\mathrm{X} 100$.

Fig. 6. After 10 weeks, showing localization of IgG within the cytoplasm of plasma cells. PAP, $\mathrm{X} 400$.

Fig. 7. After three weeks, showing infiltration of juvenile lymphocytes and plasma cells. TEM, X 2400 .

Fig. 8. After 10 weeks, showing prominent endoplasmic reticulum and enlargement of $\mathrm{F}$-type lining cells. TEM, X 8000 . 

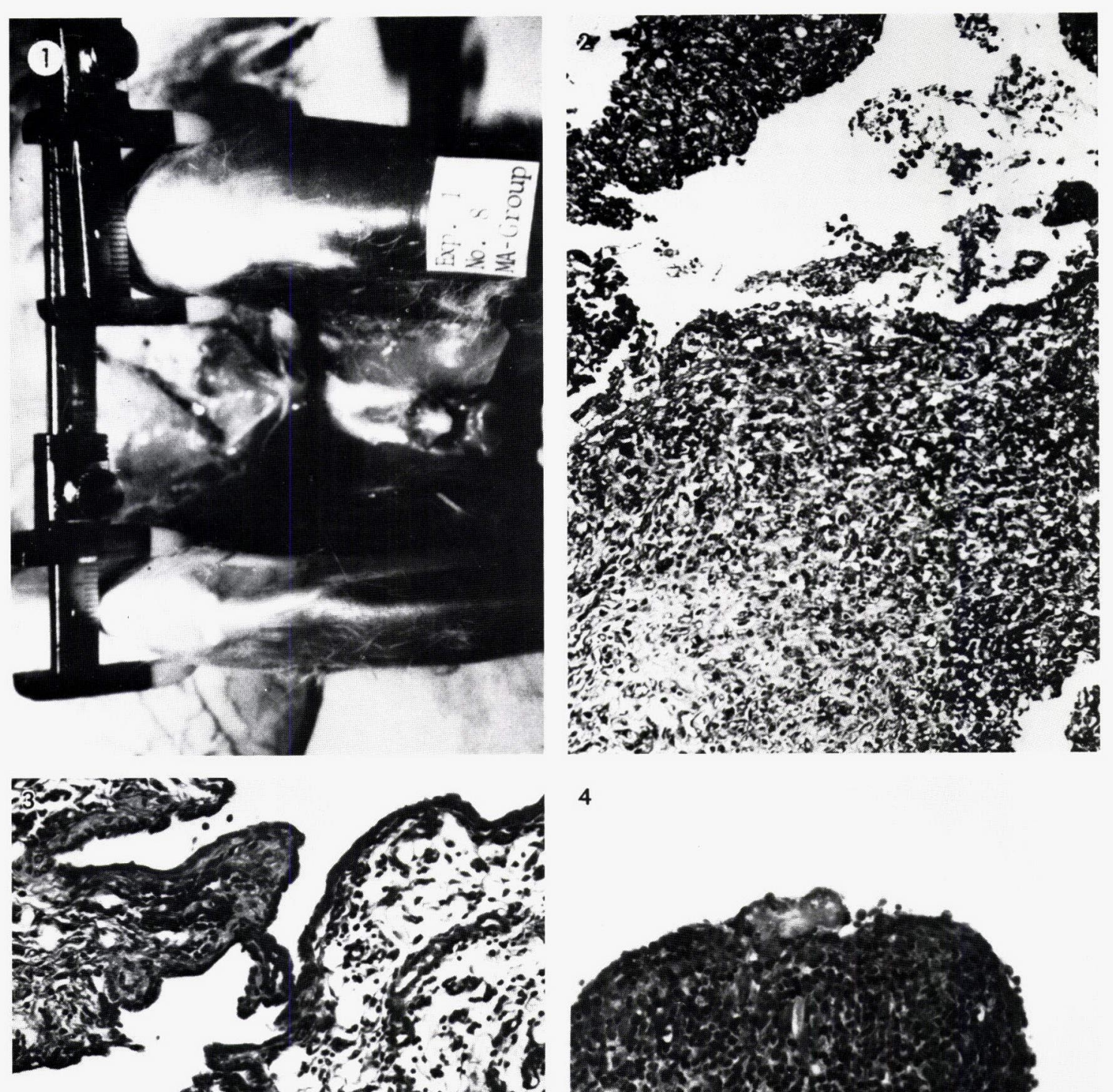
ares.

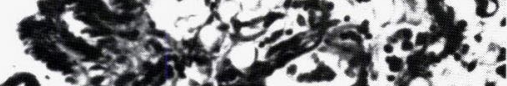

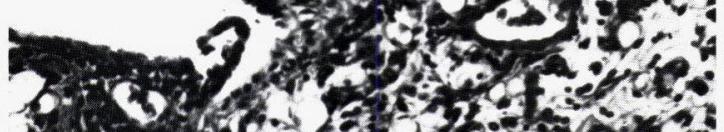

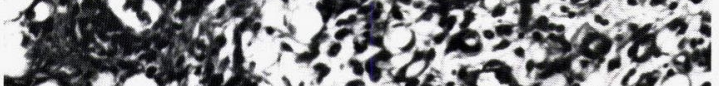

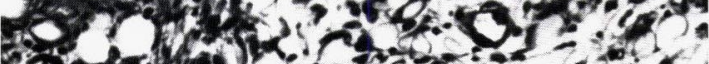

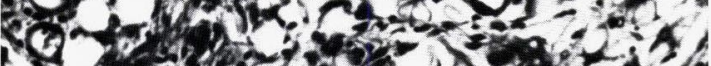

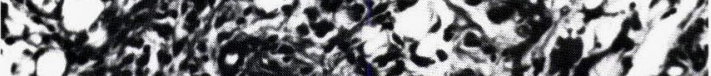

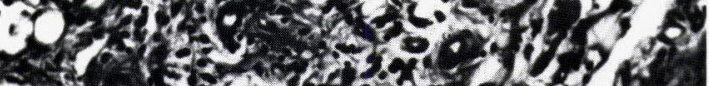

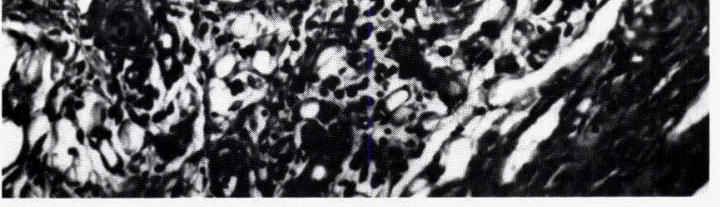

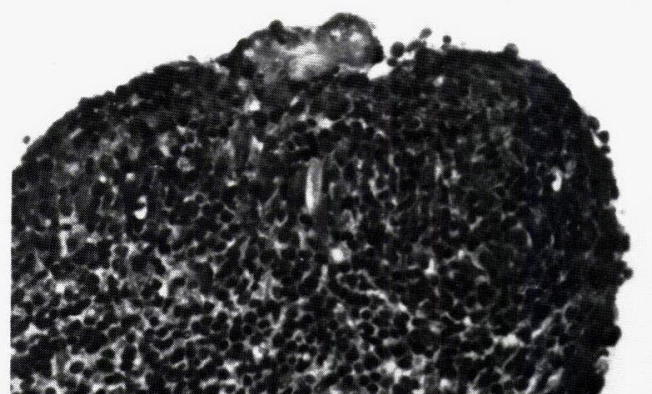

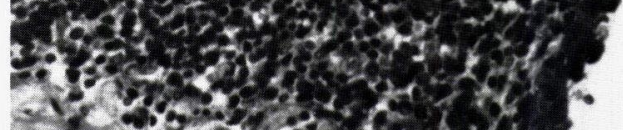

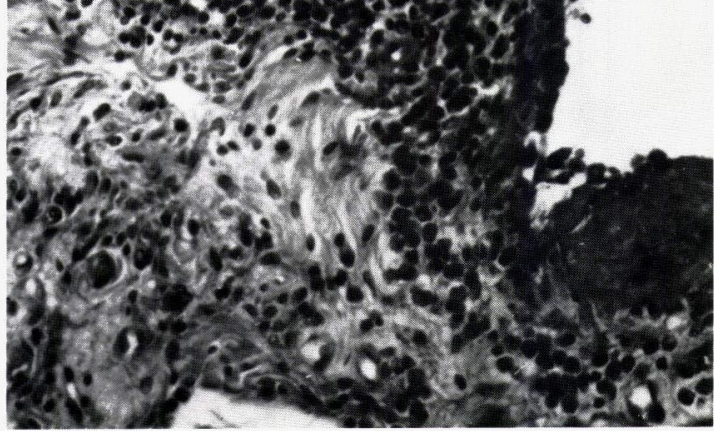



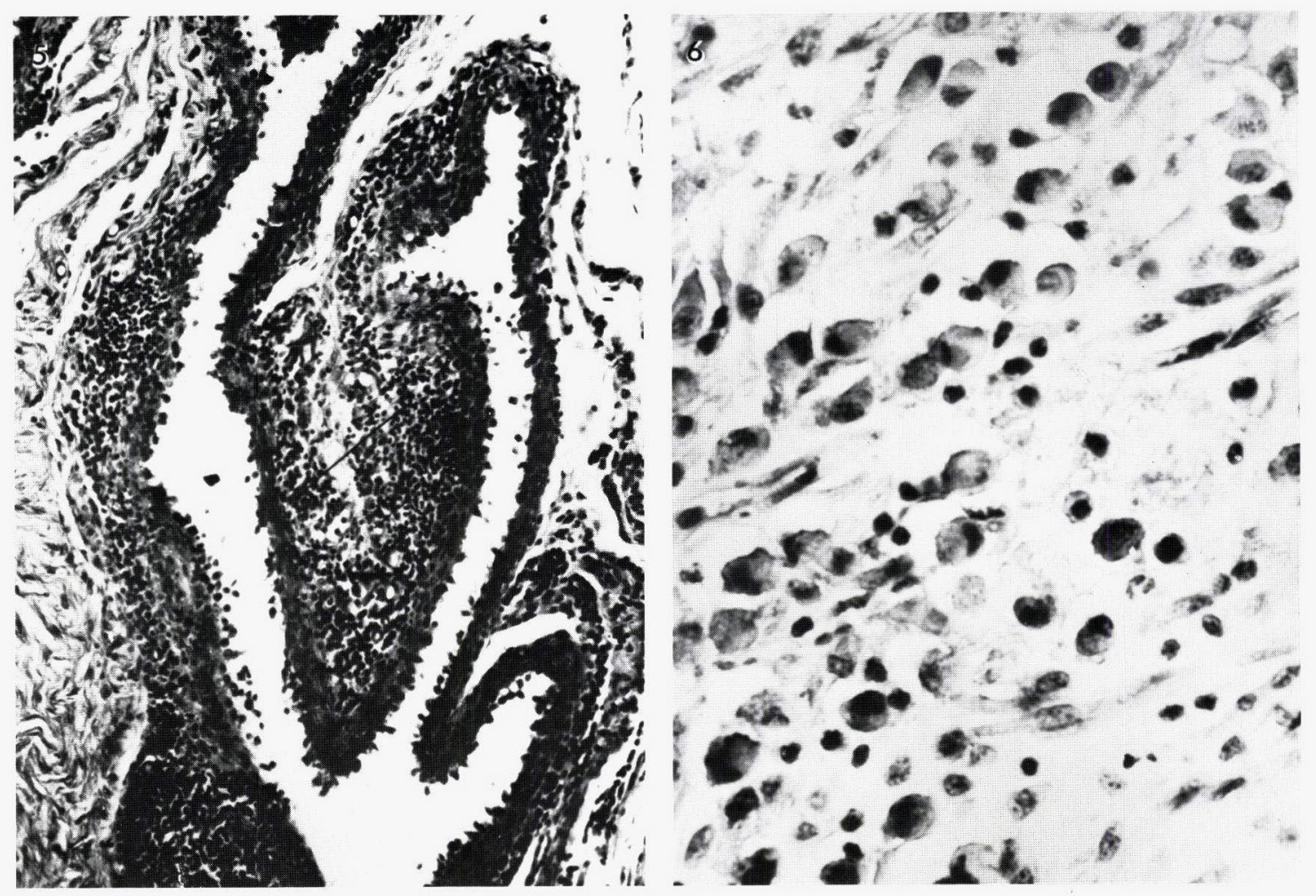

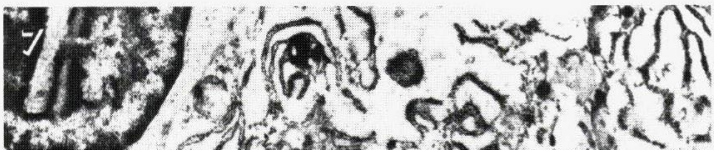

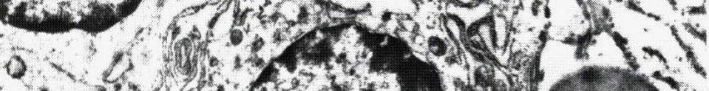

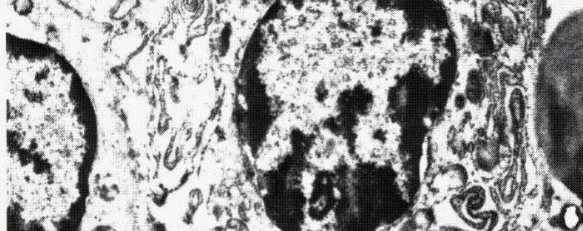

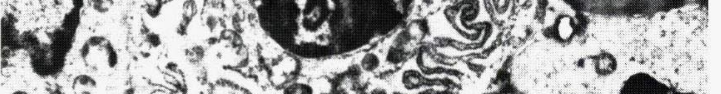

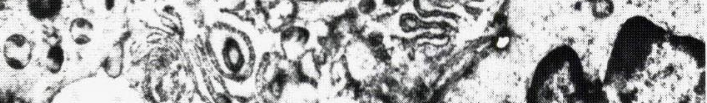
H. 7 J

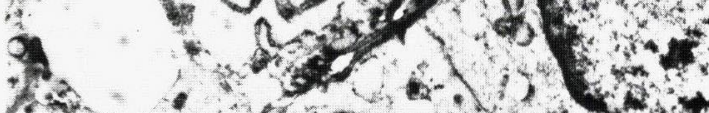

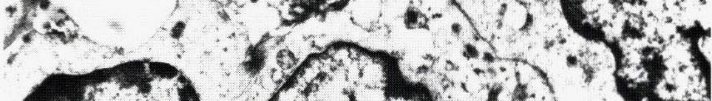
2.

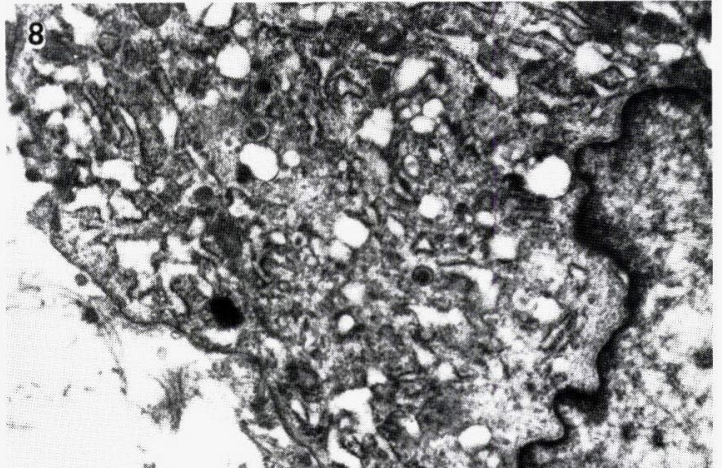

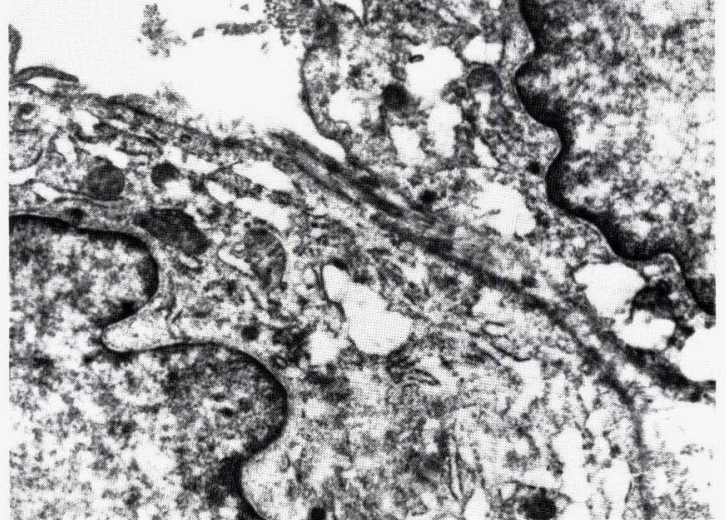

